\title{
Development of liquid biofuel market: Impact assessment of the new support system in Ukraine
}

\author{
Iryna Cheban \\ Department of Global Economics, National University of Life and \\ Environmental Sciences of Ukraine, \\ Ukraine \\ irynacheban@uk.r.net \\ ORCID 0000-0001-5265-0193
}

\section{Anatoliy Dibrova}

Department of Global Economics, National University of Life and

Environmental Sciences of Ukraine,

Ukraine

dibrova@,nubip.edu.na

Abstract In the light of the growing importance of biofuels in the world and Ukraine's potential for its production, the current research focuses on analysing future development of liquid biofuel market and production possibilities in Ukraine until 2030 using the AGMEMOD model. The AGMEMOD model is an econometric, dynamic, partial equilibrium, multi-commodity model which has the capacity to evaluate changes in Ukrainian agricultural policy and the impacts of political decisions on the agricultural sector in Ukraine. The current paper offers an introduction of state aid in the form of direct support and tax preferences for liquid biofuels producers to meet the needs of the domestic market in biofuels and to achieve the indicative target of $10 \%$ consumption biofuels in the total consumption of motor fuel by transport sector till 2020. For the quantitative assessment of these effects, the AGMEMOD model was used. The results of this study indicate that implementation of the direct state support, introduction of the system of returning and cancelling excise duty for biofuels producers will stimulate the achievement of the indicative target of $10 \%$ biofuels' consumption by the transport sector.

Keywords: liquid biofuel, econometric models, partial equilibrium, mandatory indicative target, Ukraine.

JEL Classification: Q42, C32, C51, Q28 


\section{INTRODUCTION}

The Food and Agriculture Organization of the United Nations (FAO) calls biofuels "the largest source of new demand for agricultural production in the past decade" and claims that they represent a new "market fundamental affecting prices for all cereals" (ALIMENTERRE, 2017).

Ukraine is among the largest grain and oilseed producers in the world and has abundant natural resources for further increase of its crop production. Grains and oilseeds occupy more than half of the usable agricultural area (UAA) (55\%). More than half of the country's territory is covered by highly fertile black soil known locally as "chornozem". Ukraine has around 42.7 million hectares (ha) of agricultural land. Wheat, sunflower seeds, rapeseed, and maize are the main crops, production of which is largely exportoriented (SSSU, 2017a). Throughout 2011-2017, for example, Ukraine was always the world's ten largest wheat, sunflower seeds, and maize exporters. Therefore, Ukraine has considerable potential for biomass production, including liquid biofuels. Today they are the only direct substitute for oil in transport,available on a significant scale.

Ukraine has one of Europe's highest biomass potentials for biofuels and it should be used effectively for biodiesel - 2 million tons; bioethanol - from 2 million tons to 5 million tons; biogas $\approx 35$ billion $\mathrm{m}^{3}$; solid biofuels - 40 million toe (UABio, 2012).

The research market for liquid biofuels consists of several basic segments of products: bioethanol (made from sugar and starch crops), biodiesel (made from vegetable oils) and alternative motor fuel (hereinafter - AMF) - for cars run on bioethanol.

As a member of the Energy Community, Ukraine has implemented the EU Directive 2009/28/EC on the promotion of renewable energy (RE) and committed that the share of green energy in 2020 in the overall consumption structure would be $11 \%$ (European Parliament, 2009). Taking into account the commitments undertaken by Ukraine with the accession to the Energy Community, the Resolution of the Cabinet of Ministers of Ukraine as of October 01, 2014 No. 902 titled "National Renewable Energy Action Plan for the period up to 2020" (hereinafter - NREAP) has established mandatory national indicative targets for the use of renewable energy sources with the final energy consumption in the transport sector in 2020 being 10\% (IEA, 2015).

According to the Energy Strategy of Ukraine until 2035, the share of green energy in the overall consumption will be $25 \%$ in 2035 (CMU, 2017). However, the actual results of RE's development are threatening the planned targets: in 2017, the share of renewable energy sources (RES) in the energy balance was only 1.47\% (NCSREPU, 2018), which is almost 7.5 times less than the 2020 target. According to many experts, the slow pace of growth of "green" energy in the country is conditioned by the imperfection of existing economic mechanisms managing and supporting the development of this sector. The ineffective interaction between stakeholders of various sectors of the economy: public, financial (Masharsky et al, 2018) has a significant negative impact on the development of the private sector of RE.

Provided the appropriate framework conditions it is worth to consider Ukraine's ability to achieve the above objectives for the consumption of liquid biofuels by the transport sector, analyse the state of the biofuel production in Ukraine, identify the obstacles that exist in achieving the mandatory national indicative targets, assess the feasibility of implementation taken on Ukraine's international obligations regarding motor biofuels, and propose measures to enable the obligations.

As the use of biofuels is driven by mandates - which in most countries are introduced in terms of percentage of the total fuel use - this means changes in fossil fuel use could change how biofuels are used. In general, mandates on the domestic use of bioethanol or biodiesel play an important role in modelling the demand for biofuels. Domestic mandates for biofuels can be either binding or non-binding depending on country-specific use. The mandate is non-binding if the mandated level of biofuels use is below the market 
equilibrium and binding when the domestic mandate pushes biofuels use and production beyond the conventional market equilibrium. In the case of a binding mandate, the biofuels price is above the equilibrium price, while the non-binding mandate has no effect on the market equilibrium. Where the mandate is binding, this is considered policy support to biofuels producers (OECD, 2018).

For the quantitative assessment of the above objectives, the model AGMEMOD - an econometric, dynamic model of partial equilibrium modelling the effects of changes in agrarian policy on production, consumption, imports, exports, and prices of agricultural products - was used (AGMEMOD, 2018).

The AGMEMOD includes about 50 agricultural products (including product groups) in about 35 countries (including country groups), which allows assessing the impact of policy decisions on the agrarian sector and modelling the future development of relevant indicators. For the first time, a motor biofuel market unit was created in the model and projections for the development of the liquid biofuel market in Ukraine by 2030 using the AGMEMOD model were done. The main directions of market development are identified with the introduction of support for biofuels producers in the form of direct subsidies and tax preferences, the implementation of which will ensure rapid development of the market, primarily due to the increase of biofuel production and its wide use in Ukraine and achievement of indicative targets in accordance with NREAP.

There is some research concerning using biomass and biofuels. But all of them focused on issues concerning climate change for GHG emissions reductions. For example, Gielen et al. (2002, 2003) study the optimal use of biomass for GHG emissions reductions using the BEAP model. Gül et al. (2009) utilize a global MARKAL model, denoted the Global Multi-regional MARKAL model (GMM), to analyse longterm prospects of alternative fuels in personal transport, focusing on biofuels and hydrogen. In this study, the bottom-up energy system model is linked to the climate change model MAGICC (in a similar manner as Turton, 2006). Martin Börjesson et al. (2014) investigate cost-efficient use of biofuels in road transport under system-wide CO2 reduction targets to 2050, and the effects of the implementation of targets for an almost fossil-free road transport sector to 2030 using the bottom-up, optimization MARKAL_Sweden model, which covers the entire Swedish energy system including the transport sector.

The paper is structured as follows. Section 2 deals with the modelling approach for simulation of policy impacts in the biofuel sector, Section 3 describes the data, modelling scenarios and methodology, Section 4 presents the modelling empirical results and discussion results and Section 5 concludes the study.

\section{MODELING APPROACHES FOR SIMULATION OF POLICY IMPACTS IN THE BIOFUEL SECTOR}

\subsection{Simulation models}

"No model can serve all purposes". With this statement, VAN TONGEREN et al. (2001) give an overview of the most significant models used for agricultural economic analysis and classify them following specific criteria: scope of representation, regional scope, regional unit of analysis, dynamics, trade representation, treatment of quantitative policies, availability of data and parameter estimation.

There is a rich variety of modelling techniques and models that are used for simulation of the effects of policy changes in the agriculture sector, in particular in the bioenergy sector. The modelling techniques are usually mathematical programming, simulation, and econometrics. The models may be static or dynamic; focus on single or several commodities; deal with the entire economy, i.e., general equilibrium models, or one or several sectors, i.e., partial equilibrium models; and the modelling results may be aggregated to regional, national or multinational levels. The models may consider bilateral trade flows; or the world market may be represented as a point market (APD, 2017). Depending on the purpose of the analysis, synergies of 
mathematical programming, simulation and econometric techniques, as well as the other estimation methods, such as, for example, genetic algorithms or investment appraisal methods may be used for modelling of the bioenergy sector.

One of the examples of such models that are used for policy advice at the EU level and at the whole world is the Aglink-Cosimo model. The biofuels component of the Aglink-Cosimo model is a structural economic model that analyses the world supply and demand for bioethanol and biodiesel. The biofuels module is a recursive dynamic, partial equilibrium model used to simulate the annual market balances and price for the production, consumption and trading quantity of bioethanol and biodiesel worldwide. This model is completely integrated into the cereals, oilseeds and sugar component of the Aglink-Cosimo model. The production of biofuels drives the additional demand for agricultural commodities, in particular, coarse grains, vegetable oil, and sugar. The biofuels module is linked to the other components of the AglinkCosimo model mainly via the food-based feedstocks demand, which includes, amongst other commodities, maize, sugar, wheat, and rice (OECD, 2018).

Joint Research Center was carried out research "Impacts of the EU Biofuel Target on Agricultural Markets and Land Use A Comparative Modelling Assessment" was analyzing the impacts and consequences of biofuel policies using one or other of the three models that are used for study (namely ESIM, AGLINKCOSIMO, and CAPRI) as well as several studies based on the IMPACT and the GTAP models (Mueller and Pérez Domínguez, 2008).

The MIRAGE (Modelling International Relationships in Applied General Equilibrium) global computable general equilibrium model (CGE) which allows conducting a quantitative analysis of the global economic and environmental impact of biofuel development. Primary among major methodological innovations introduced in the model there is the new modelling of energy demand, which allows for substitutability between different sources of energy, including biofuels. This is facilitated by the extension of the underlying Global Trade Analysis Project (GTAP) database, which separately identifies bioethanol with four subsectors, biodiesel, five additional feedstock crops sectors, four vegetable oils sectors, fertilizers, and the transport fuel sectors. The model was also modified to account for the co-products generated in the bioethanol and biodiesel production processes and their role as inputs to the livestock sector. This model assesses the greenhouse gas emissions (focusing on CO2) associated with direct and indirect land - use changes as generated by the model for the year 2020 (ATLASS Consortium, 2010). The version of GTAP used in the studies by Hertel et al. (2008) and Taheripour et al. (2008a), known as GTAP-E, has been specially extended to deal with biofuel and climate change policies.

The MARKAL Sweden energy system model is an application of the well-established MARKAL model and can be described as a dynamic, bottom-up, partial equilibrium energy system model (Gül et al., 2009). Through optimization, the model provides the overall welfare-maximizing system solution that meets the defined model constraints over the studied time horizon. Welfare-maximization implies that the cost of energy service supply and costs due to losses in consumer surplus are minimized. MARKAL Sweden applies a long-term time horizon reaching from 1995 to 2050. The model applies a comprehensive view of the Swedish energy system and describes all relevant sectors including electricity, district heating, industry, transport, premises and services (Börjesson Hagberg et al., 2016).

The partial equilibrium (PE) ESIM model, in the version used in the study by Banse and Grethe (2008), contains explicit supply and demand functions for biodiesel and ethanol. It distinguishes three feedstocks for each biofuel and differentiates them further according to whether or not they have been grown on set-aside land. The model considers four by-products: gluten feed and meals from three different oilseed crops. SIM models each EU Member State individually incorporates a wide range of EU agricultural domestic and trade policies and endogenously determines a very rich set of agricultural prices. However, fossil energy prices are taken as exogenous and, being a comparative static model, it does not allow for any 
lagged adjustment (adjustments to price changes or other shocks that take place within the current year). Net trade flows are endogenous.

There are many other models for biofuel and bioenergy development simulation. However, they all take into account and assess the impact of the setting of indicative targets under Directive 2009/28/EC and the environmental performance of the EU biofuel policy as concretized in the RED. Nevertheless, our aim is to show what models are, what methodology do they have and use of their approaches for our research. Because we at the first time among other countries have included in the model, implemented Ukrainian liquid biofuel market within the framework into AGMEMOD model (AGMEMOD UA).

Moreover, in the current research, the AGMEMOD model is used because of its advantages in comparison to the models and approaches reviewed above. The AGMEMOD model stands for Agricultural Member State Modelling and was established in 2001. We chose this model because it is a partial equilibrium, dynamic, multi-country and multi-market model that is used for analyzing the effects of agricultural policies the respective sectors of the European Union (EU) and on the respective sectors of Ukraine (AGMEMOD, 2018).

The assess empirically the impacts of the 2003 reform of the Common Agricultural Policy (CAP) on the agri-food sector in Finland was researched by Csaba Jansik et al. (2014). The AGEMOD model is widely used by the European Commission that made a lot of different issues concerning policy, administration and industry need medium-term projections of the expected developments in the agri-food markets for their decision-making processes. The EU Commission presents such projections for the EU (Petra Salamon et al., 2019).

Since 2012 Ukraine country block AGMEMOD UA has been included in the AGMEMOD model (BANSE et al., 2012). In this part of the model, we have added a new liquid biofuel sector: bioethanol (included alternative motor fuel based on bioethanol) and biodiesel sectors. Most of the equations in the model have been estimated using annual data over the period 1973-2017, or over shorter periods in case of data were not available (such as for the new member states).

The variables entering in each sub-model represent consecutive positions in the balance sheet of each market. On the supply side the beginning stocks, production, and imports are being considered and on the demand side the domestic use, exports and ending stock are modeled. For each product in each country, also the respective domestic prices (market-clearing prices) are modeled. The equilibrium in each market is reached in the model also on the level of the whole EU. The necessary condition for the model to be solved is that the equality between supply and demand in each market in each country must hold (Hamulczuk \& Hertel, 2009). The general structure of the model is presented below (see Figure 1).

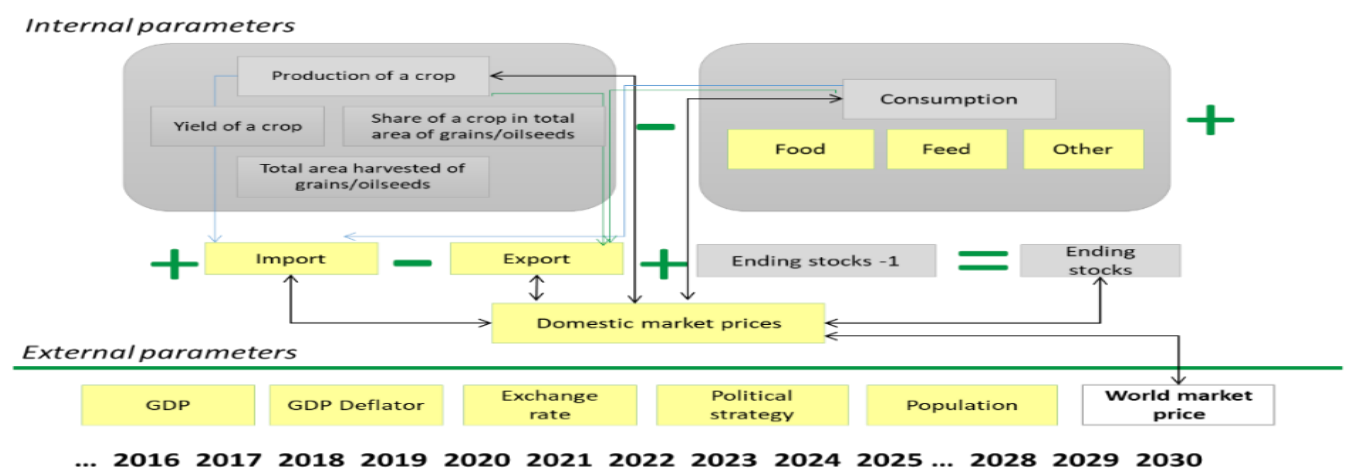

Figure 1. AGMEMOD model structure

Source: German-Ukrainian agricultural policy dialogue (2018) 
The main advantages of the AGMEMOD model include:

- the model simulates a wide range of agricultural product markets and related parameters such as market prices, production, consumption, import, export, yield and land use.

- the model can simulate the effects of the policy reforms that are of key interest for the current project.

- the model considers changes in the general economic environment. In particular, GDP and population growth rates, as well as the currency exchange rate, are taken into account as exogenous parameters.

- $\quad$ the model is dynamic and allows modelling changes on a year-to-year basis.

- most of the core functions of the model are estimated econometrically. The results of such an estimation provide a more realistic outcome in terms of parameter estimation and choice of the functional form in comparison to the results of the calibration.

- the model is disaggregated to regional and producer group levels that allow considering of regional and producer differences in the effects of policy changes and development of the sector.

\section{MODELING SCENARIOS OF THE LIQUID BIOFUELS DEVELOPMENT}

\subsection{Data description}

To create projections of liquid biofuels development, AGMEMOD uses a combination of exogenous and endogenous data (parameters). A change in exogenous variables may determine the assumptions of scenarios simulated by the model.

Future values of variables (by 2030) that are exogenous to the model (that is, not estimated by the model), such as GDP, GDP deflator, exchange rate of the national currency, the population of Ukraine and world prices for diesel, gasoline, gasoline and diesel consumption in Ukraine, as well as excise duty on alternative motor fuel, on gasoline and biodiesel, are forecast estimates of various institutions. The separate exogenous variables of AGMEMOD Ukraine are shown in Table 1. The data for our research was collected from publications of State Statistics Service of Ukraine (SSSU), personal communication with the largest biofuel producer in Ukraine "Ukrspyrt" and with Ukrainian, an association of alternative fuels producers "Ukrbiopalivo". Historical and projected values of world market prices, national Gross Domestic Product (GDP), GDP deflator, currency exchange rate, and population growth rate are acquired from United States Department of Agriculture (USDA), Food and Agriculture Organization of the United Nations (FAO) and EU Agricultural Outlook. If necessary, data are not available, they are estimated as projections from the previous periods. Using data collected, equations representing the indicators of the biofuel market in Ukraine are estimated as time-series regressions. They are then introduced into the AGMEMOD Ukraine country model. 
Table 1

The exogenous variables of AGMEMOD Ukraine

\begin{tabular}{|c|c|c|c|c|c|c|c|c|c|c|}
\hline Indicators & $\begin{array}{c}\text { Units of } \\
\text { measurement }\end{array}$ & 2018 & 2020 & 2022 & 2024 & 2026 & 2027 & 2028 & 2029 & 2030 \\
\hline Diesel price & UAH / $100 \mathrm{~kg}$ & 2275 & 2617 & 2793 & 2911 & 2955 & 2989 & 3026 & 3068 & 3094 \\
\hline Gasoline price & UAH / $100 \mathrm{~kg}$ & 2464 & 2878 & 3126 & 3251 & 3244 & 3264 & 3292 & 3327 & 3340 \\
\hline $\begin{array}{l}\text { Excise duty on } \\
\text { motor alternative } \\
\text { fuel }\end{array}$ & UAH / $100 \mathrm{~kg}$ & 451 & 428 & 370 & 365 & 362 & 360 & 358 & 356 & 354 \\
\hline $\begin{array}{l}\text { Bioethanol } \\
\text { consumption of } \\
\text { from sugar beet } \\
\text { (indicative target of } \\
10 \% \text { ) }\end{array}$ & thousand tons & 45.3 & 78.4 & 153 & 228 & 303 & 340 & 378 & 415 & 452.7 \\
\hline $\begin{array}{l}\text { Bioethanol } \\
\text { consumption of } \\
\text { from wheat } \\
\text { (indicative target of } \\
10 \% \text { ) }\end{array}$ & thousand tons & 1.3 & 3.6 & 5.91 & 8.21 & 10.5 & 11.6 & 12.8 & 13.9 & 15.1 \\
\hline $\begin{array}{l}\text { Bioethanol } \\
\text { consumption of } \\
\text { from maize } \\
\text { (indicative target of } \\
10 \% \text { ) }\end{array}$ & thousand tons & 2.7 & 7.2 & 11.8 & 16.4 & 21 & 23.3 & 25.6 & 27.9 & 30.2 \\
\hline $\begin{array}{l}\text { Bioethanol } \\
\text { consumption of } \\
\text { from rye (indicative } \\
\text { target of } 10 \% \text { ) }\end{array}$ & thousand tons & 0.4 & 1.2 & 1.97 & 2.7 & 3.5 & 3.8 & 4.3 & 4.6 & 5.03 \\
\hline $\begin{array}{l}\text { Excise duty on } \\
\text { gasoline }\end{array}$ & UAH / $100 \mathrm{~kg}$ & 555 & 527 & 455 & 450 & 446 & 443 & 441 & 438 & 436 \\
\hline $\begin{array}{l}\text { Gasoline } \\
\text { consumption }\end{array}$ & UAH / $100 \mathrm{~kg}$ & 2143 & 2249 & 2306 & 2306 & 2316 & 2317 & 2318 & 2325 & 2341 \\
\hline $\begin{array}{l}\text { Excise duty on } \\
\text { diesel }\end{array}$ & UAH / $100 \mathrm{~kg}$ & 407 & 385 & 333 & 329 & 326 & 324 & 323 & 321 & 319 \\
\hline $\begin{array}{l}\text { Excise duty on } \\
\text { biodiesel }\end{array}$ & UAH / $100 \mathrm{~kg}$ & 316 & 300 & 259 & 256 & 254 & 252 & 251 & 250 & 248 \\
\hline $\begin{array}{l}\text { Biodiesel } \\
\text { consumption }\end{array}$ & thousand tons & 5057 & 5000 & 4934 & 4869 & 4779 & 4753 & 4734 & 4716 & 4700 \\
\hline
\end{tabular}

Source: The separate exogenous variables of AGMEMOD Ukraine 2019; Authors' results.

\subsection{Modeling scenarios}

To assess the development of the motor biofuel market (bioethanol, alternative motor fuel, biodiesel), the following scenarios were developed for the achievement of the above-mentioned goals: "Policy_10\%", "Direct support_10\%", "Direct support", "Returning excise duty", "Cancelling excise duty" and "Baseline Scenario".

The "Policy_10\%" scenario is designed to assess the required level of bioethanol consumption from different crops (wheat, corn, rye, sugar beet) and biodiesel (rapeseed and sunflower oil) based on the performance of the - NREAP in order to determine the amount of bioethanol, AMF and biodiesel consumption to achieve $10 \%$ of biofuels in the total consumption of motor fuels by 2030 (Table 2). 
Table 2

Assessment of the contribution of energy from renewable sources to the transport sector to achieve the mandatory indicative targets for 2020 , ktoe

\begin{tabular}{|l|c|c|c|c|c|c|}
\hline \multirow{2}{*}{ Types of energy sources for use in the transport sector } & \multicolumn{2}{|c|}{$\mathbf{2 0 1 8}$} & \multicolumn{2}{|c|}{$\mathbf{2 0 1 9}$} & \multicolumn{2}{|c|}{$\mathbf{2 0 2 0}$} \\
\cline { 2 - 8 } & ktoe & GW-h, kt & ktoe & GW-h, kt & ktoe & GW-h, kt \\
\hline $\begin{array}{l}\text { Bioethanol/ } \\
\text { Ethyltert-Butyl Ether, produced from bioethanol }\end{array}$ & 250 & 393 & 280 & 440 & 320 & 503 \\
\hline Biodiesel & 50 & 56 & 60 & 68 & 70 & 79 \\
\hline
\end{tabular}

Source: Summarized by the author on the basis of NREAP

Due to NREAP, these indicators should be achieved by 2020. Taking into account the low level of liquid biofuels production in Ukraine in 2017, achieving these indicative targets is impossible until 2020 without state support. Therefore, the values of bioethanol and biodiesel consumption were calculated from 2018 to 2030. It should be noted that according to the scenario "Policy_10\%" Ukraine needs to reach 503 thousand tons of bioethanol and AMF consumption and 79 thousand tons of biodiesel by 2030 (Table 3).

Table 3

Volume of consumption of liquid biofuels to achieve $10 \%$ biofuel use in the overall structure of motor fuels by 2030

\begin{tabular}{|c|c|c|c|c|c|c|c|c|}
\hline \multirow{2}{*}{ Year } & \multicolumn{2}{|c|}{$\begin{array}{c}\text { Indicative target } 10 \% \text { according to NREAP, } \\
\text { kt, }\end{array}$} & \multicolumn{2}{|c|}{$\begin{array}{l}\text { Bioethanol and products based on } \\
\text { Breakdown by } 2030\end{array}$} & \multicolumn{3}{|c|}{$\begin{array}{c}\text { Biodiesel and } \\
\text { products based on it }\end{array}$} \\
\cline { 2 - 10 } & bioethanol & biodiesel & $\begin{array}{c}\text { Sugar } \\
\text { beet }\end{array}$ & wheat & maize & rye & $\begin{array}{c}\text { Rapeseed } \\
\text { oil }\end{array}$ & $\begin{array}{c}\text { Sunflower } \\
\text { oil }\end{array}$ \\
\hline 2018 & 49.67 & 6.08 & 45.25 & 1.33 & 2.65 & 0.44 & 3.65 & 2.43 \\
\hline 2020 & 90.48 & 18.23 & 78.41 & 3.62 & 7.24 & 1.21 & 10.94 & 7.29 \\
\hline 2030 & 503.00 & 79.00 & 452.7 & 15.09 & 30.18 & 5.03 & 47.4 & 31.6 \\
\hline
\end{tabular}

Source: Authors' results.

To calculate the above indicators, the following assumptions were taken into account: $90 \%$ of the total consumption in the bioethanol sector could be achieved by producing bioethanol and AMF from sugar beet, $6 \%$ from corn, $3 \%$ from wheat, $1 \%$ from rye. As for indicators in the biodiesel sector, consumption of 79 thousand tons of biodiesel in total fuel consumption can be achieved by using $60 \%$ biodiesel of rapeseed oil and 40\% from sunflower oil.

Today in Ukraine there is no direct support and incentives for the production of liquid biofuels and development of the appropriate market. However, given the situation on the liquid biofuel market, the achievement of $10 \%$ of RES in the transport sector by 2020 is impossible without government support. That why we should assess the effect, implementing direct support and tax preferences for bioethanol and biodiesel producers on further biofuel development.

The "Direct Support_10\%" scenario is designed to assess the implications of introducing a new producer support system in the form of direct subsidies to stimulate and expand biofuel production and achieve 10\% biofuel consumption (bioethanol, alternative motor fuel, biodiesel) in total consumption of motor fuels. Support is provided for producers who process the above products into bioethanol, alternative motor fuel, and biodiesel and depending on the volume of these produced biofuels.

The size of direct support in the AGMEMOD model implemented in the form of price additions in the calculation of UAH per $100 \mathrm{~kg}$ of preferential products. Pricing additions are included in scenario 
equations, which results in calculating the impact on biofuel production. To model the "Direct Support_10\%" scenario, it was necessary to determine the total amount that would be allocated from the budget to the support program in the form of direct budget subsidies to bioethanol producers, components based on it and biodiesel. This was done by expert estimation and using the AGMEMOD model.

To achieve $10 \%$ biofuel consumption by the transport sector in the total consumption of motor fuel, the support for bioethanol producers, alternative motor fuel, biodiesel and mixtures based on it was 5500 $\mathrm{UAH} / 100 \mathrm{~kg}$ of the finished product. To simulate the state support scenario, this amount of subsidies was calculated as per UAH / $100 \mathrm{~kg}$, which is then added to the producer price of the product that is being subsidized, and is applied in the equations of the processing model and affects the production and consumption of the product concerned.

The "Direct Support" scenario is designed to assess the implications of introducing a new system of direct support for producers, calculated and estimated depending on the expected level of gasoline and diesel consumption by 2030 to meet the needs of consumers in bioethanol, alternative motor fuel and biodiesel in the domestic motor fuel market.

Demand for bioethanol, alternative motor fuel, and biodiesel is closely related to the consumption of gasoline and diesel, respectively, since bioethanol is used as an octane-enhancing additive for the production of traditional gasoline and alternative motor fuels, and biodiesel as an octane-enhancing additive for the production of conventional diesel and products based on them. Based on the data of gasoline consumption in Ukraine for the period from 2012 to 2017, the calculation of the demand for bioethanol for Ukraine was made, depending on the consumption of gasoline and the percentage of bioethanol in it, respectively, $5 \%$, $7 \%, 10 \%$ during the period from 2012-2017.

In 2017, the transport sector consumed 1986 thousand tons of gasoline and 5149 thousand tons of diesel fuel. Let's assume that the same approximate proportions of fuel consumption for energy content (30\% of gasoline, $70 \%$ of diesel) will be saved until 2020 , and it will be necessary to ensure the replacement of approximately $30 \%$ of gasoline, $70 \%$ diesel.

Therefore, to maintain the current structure of fuel consumption by the transport sector (in particular, for preserving the approximate share of vehicles on gasoline and diesel) at 2017 levels, to provide 10\% energy consumption from RES by the transport sector, it will be need 109323 thousand tons of fuel equivalent bioethanol and 325 thousand tons of fuel equivalent biodiesel. It is worth noting that State Enterprise "Ukrspirt" may produce 160 thousand tons per year at existing production capacities. Consequently, it is theoretically possible to provide the required amount of bioethanol (152 thousand tons) by 2020 . To do this, it is enough to load at the full power plants of the State Enterprise "Ukrspirt".

The "Returning excise duty" scenario is designed to assess the implications of introducing a new support system for alternative motor fuels producers and biodiesel producers in the form of returning excise duty to producers from the sales of alternative motor fuels and biodiesel for a year. The scenario "Returning excise duty" was implemented in the form of price additions - the excise duty on alternative motor fuel and biodiesel in the calculation of UAH per $100 \mathrm{~kg}$ of preferential products, which is then added to the price of the producer of the product and is applied in the equations of the model of processing and affects the production and consumption of the products concerned.

The "Cancelling excise duty" scenario is designed to assess the consequences of the abolition of the excise duty on the sale of alternative motor fuels and biodiesel produced by these biofuels' producers. The tool for supporting the development of this sector is the tax exemption for bioethanol and biodiesel as an excisable product. According to the Tax Code of Ukraine, as of 01.11.2018, excise duty on the alternative motor fuel was 130 EUR / $1000 \mathrm{~kg}$, biodiesel - 91.2 EUR / $1000 \mathrm{~kg}$ (Verkhovna Rada of Ukraine 2014).

In 2030, the amount of excise duty per $100 \mathrm{~kg}$ of alternative motor fuel production will amount to $353.63 \mathrm{UAH} / 100 \mathrm{~kg}$, and biodiesel - $248.08 \mathrm{UAH} / 100 \mathrm{~kg}$. If we cancel the above types of excise, then 
the producers price of alternative fuel motor will increase by 5\% in 2030 (from $2338.8 \mathrm{UAH} / 100 \mathrm{~kg}$ to 2 $456.1 \mathrm{UAH} / 100 \mathrm{~kg}$ ), the producers price of biodiesel and products based on it will increase by $13.27 \%$ (from $2637.3 \mathrm{UAH} / 100 \mathrm{~kg}$ to $2987.2 \mathrm{UAH} / 100 \mathrm{~kg}$ ).

It follows that producing bioethanol for the producer will be more profitable than producing alternative motor fuel since bioethanol is not an excisable product, but alternative motor fuel is excisable goods and the price of alternative motor fuel includes the corresponding excise duty. As for the biodiesel production, as expected, the abolition of excise duty for the producer will increase its production and will increase profitability.

The "Baseline scenario"- based on the assumption that during the projected period 2018-2030, the policy framework conditions in general in Ukraine remain at 2017 level and the biofuel sector does not receive any state support from 2018 on. This also means that the model considers such factors as conditions of Deep and comprehensive free trade area agreement (DCFTA) as well as other trade regulations, military conflicts in the Donbas region and annexed Crimea, which is excluded from modelling as they were in 2017.

\section{EMPIRICAL RESULTS AND DISCUSSION}

Below we will present the results of the modelling of the liquid biofuel market in Ukraine using the AGMEMOD model under the scenarios "Direct support_10\%", "Direct support", "Returning excise duty", "Cancelling excise duty" compared to the Baseline scenario. These results reflect changes in the production, consumption, import and export of bioethanol, alternative motor fuels, biodiesel and products based on it in Ukraine up to 2030.

For the analysis of the results of simulation of support scenarios and tax preferences, consideration should first be given to changing the price of bioethanol, alternative motor fuel, and biodiesel when introducing each type of support and tax preferences to the biofuels producers concerned. As noted above, the size of support in the AGMEMOD model implemented in the form of price additions in the calculation of UAH per $100 \mathrm{~kg}$ of preferential products. Pricing additions are included in the scenario equations, which results in calculating the impact on biofuel production. The modelling results of price additions and changes presented in producer prices in 2030 compared to the Baseline scenario (Table 4).

Table 4

The modelling results of price additions and changes presented in producer prices in 2030

\begin{tabular}{|c|c|c|c|c|c|c|}
\hline \multirow{2}{*}{ Product } & \multicolumn{2}{|c|}{ Price additions in 2030, UAH / $100 \mathrm{~kg}$} & \multicolumn{3}{c|}{$\begin{array}{c}\text { Change in producer prices in 2030 compared to } \\
\text { Baseline scenario, \% }\end{array}$} \\
\cline { 2 - 7 } & $\begin{array}{c}\text { "Direct } \\
\text { support_10" }\end{array}$ & $\begin{array}{c}\text { "Direct } \\
\text { support" }\end{array}$ & $\begin{array}{c}\text { "Returning } \\
\text { excise duty" }\end{array}$ & $\begin{array}{c}\text { "Direct } \\
\text { support_10" }\end{array}$ & $\begin{array}{c}\text { "Direct } \\
\text { support" }\end{array}$ & $\begin{array}{c}\text { "Returning } \\
\text { excise duty" }\end{array}$ \\
\hline Bioethanol & 8142.9 & 1480.54 & 0 & +331.53 & +60.28 & - \\
\hline AMF & 8142.9 & 1480.54 & 353.63 & +348.17 & +63.3 & +15.12 \\
\hline Biodiesel & 8142.9 & & 248.08 & +308.76 & & +9.41 \\
\hline
\end{tabular}

Source: Authors' results.

Table 4 illustrates that in the "Direct Support_10\%" scenario, the largest price additions in 2030 estimated for all products presented in modelling (bioethanol, alternative motor fuel and biodiesel). The growth of prices in comparison with the Basic Scenario was also the highest for bioethanol $(+331.53 \%)$, AMF (+ 348.17\%) and biodiesel (+ 308.76\%). According to the" Direct Support" scenario, we find the largest price additions for bioethanol and AMF, as well as price increases compared to the Baseline scenario, respectively, the largest for bioethanol $(+60.28 \%)$ and AMF $(+63.3 \%)$. 
Since the distribution of budget subsidies directly depends on the size of production of each product accumulated by the sector, the sectors that produce less receive fewer subsidies. Under the "Returning excise" scenario, the largest price additions are for the AMF, and the increase in prices compared to the Baseline scenario for the AMF was (+15.12\%), for biodiesel (+ 9.41\%). From the above, it follows that, as expected, the simulation results received the greatest effects and price additions with the direct support of biofuel producers.

The results of the "Direct Support_10\%" scenario indicate that support for bioethanol producers, alternative motor fuel and biodiesel producers in the form of direct subsidies will positively contribute to the rapid development of the bioethanol and biodiesel sector and will give an impetus for achieving the indicative target of $10 \%$ bioethanol, AMF consumption by 2020 , reaching the consumption of alternative motor fuel at the level of 540.06 thousand tons, bioethanol 540.08 thousand tons, and biodiesel almost 79 thousand tons by 2030 in the total consumption of transportation fuel. Comparing the simulation results with the Baseline scenario, in 2030, the bioethanol production with state support will increase from 12.91 thousand tons to 445.87 thousand tons, almost by 34.5 times (Figure 2).

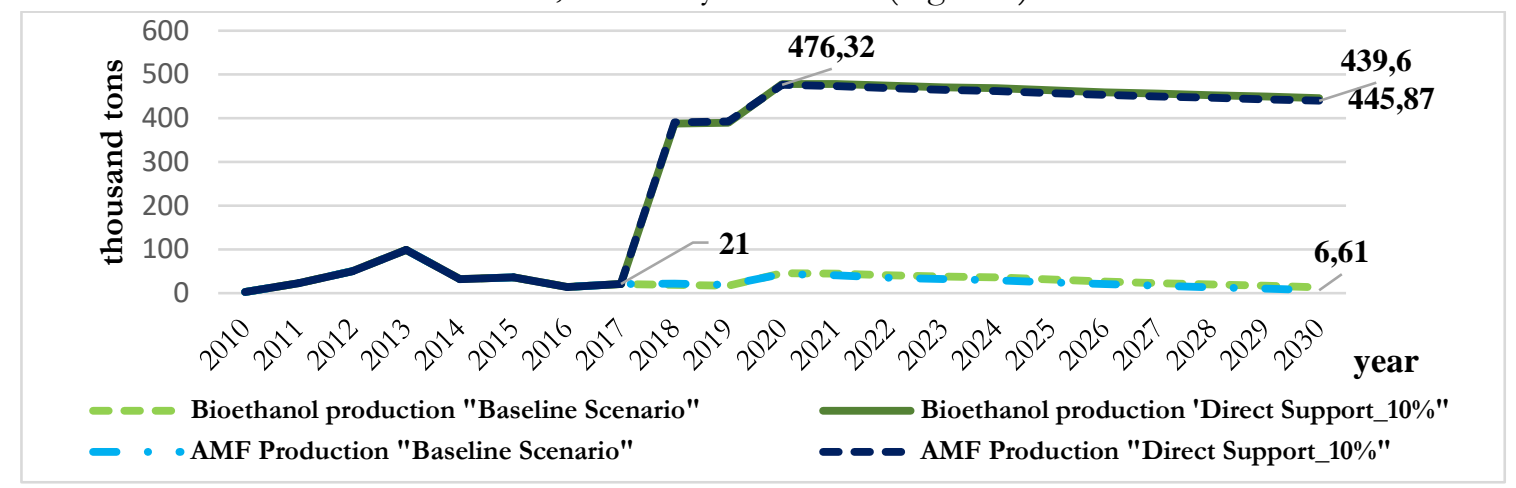

Figure 2. Bioethanol and AMF production in the "Direct Support_10\%" scenario compared to the Baseline scenario

Source: own evaluation.

By analysing the modelling results of biofuel domestic use in the "Direct support_10\%" scenario, bioethanol domestic use by 2030 will increase from 90.38 thousand tons to 538.5 thousand tons (by 5.96 times), alternative motor fuel - from 89.98 to 538.13 thousand tons (by 5.98 times), biodiesel - up to 78.81 thousand tons (Figure 3).

Provided the low level of bioethanol and alternative motor fuel production and the almost absence production of biodiesel, it is clear that in order to achieve indicative targets by 2020 , it is required to allocate significant amount of money for this purpose: $5500 \mathrm{UAH} / 100 \mathrm{~kg}$ of finished products in order to receive more than 500 thousand tons bioethanol (alternative motor fuel) consumption by 2020 and $5500 \mathrm{UAH} /$ $100 \mathrm{~kg}$ to reach biodiesel consumption of 79 thousand tons by 2030 .

The results of the "Direct Support" scenario indicate that direct support will positively influence the rapid development of the bioethanol sector to meet the needs of the domestic market. Thus, the bioethanol production will increase by 7 times (from 12.91 to 90.6 thousand tons) compared to the Baseline scenario, and the alternative motor fuel - almost by 12.75 times (from 6.61 to 84.31 thousand tons). As regard to bioethanol domestic use will increase from 90.38 to 170.85 thousand tons (by 1.89 times), alternative motor fuel - from 89.98 to 170.4 (by 1.89 times). 


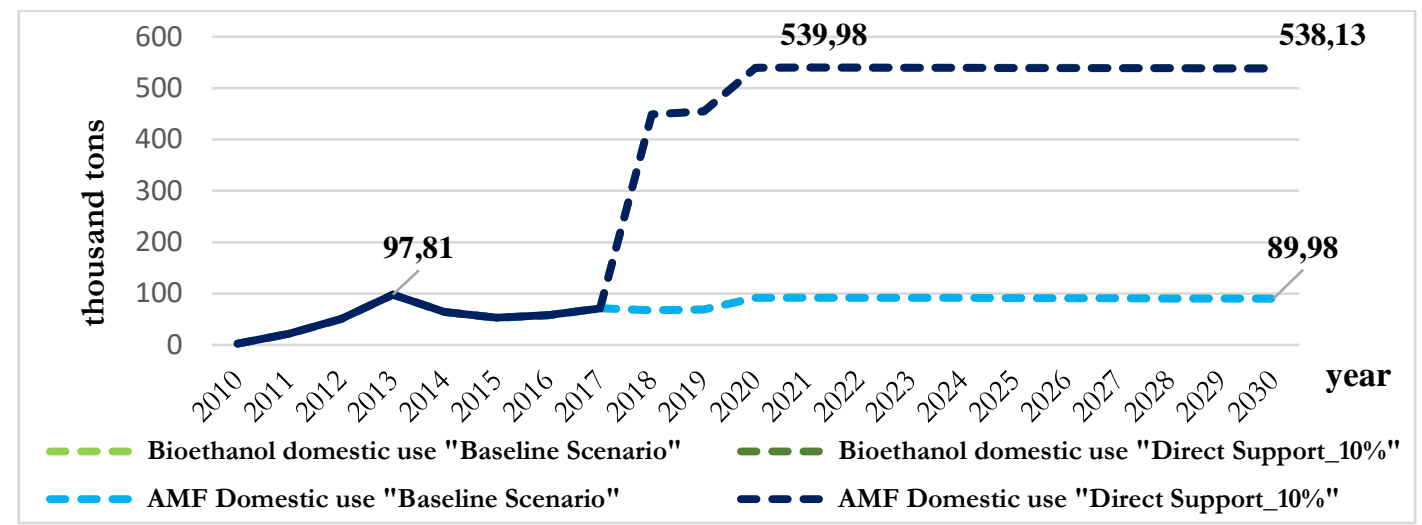

Figure 3. Bioethanol and AMF domestic use in the "Direct Support_10\%" scenario compared to the Baseline scenario

Source: own evaluation.

From the above, it follows that the support of biofuels producers in the form of direct state subsidies for bioethanol and AMF producers at the level of $1000 \mathrm{UAH} / 100 \mathrm{~kg}$, as expected, will contribute to the increase of biofuel production and its use to meet the domestic needs of transportation fuel market in Ukraine. The calculations show that 152.5 thousand tons of bioethanol is required to meet the needs of the domestic market. The simulation results have confirmed that in 2020, due to direct subsidies for bioethanol and alternative motor fuel producers, starting in 2018 at a rate of $1000 \mathrm{UAH} / 100 \mathrm{~kg}$, bioethanol consumption in the volume of 172.82 thousand tons could be achieved, AMF for such same conditions 172.71 thousand tons.

The introduction of the system of returning excise duty for AMF producers will stimulate the increase of the AMF production, in comparison with the Baseline scenario, almost by 3.87 times (from 6.61 to 25.62 thousand tons), and its domestic use in 2030, respectively, will increase by 1.2 times (from 89.98 thousand tons to 109.72 thousand tons). However, as compared with the direct support scenarios for producers of biofuels, as expected, production and consumption rates are somehow lower.

The introduction of returning excise duty system for biodiesel producers for the sold biodiesel will stimulate an increase in biodiesel production, compared to the Baseline Scenario by 6 times (from 0.01 to 0.06 thousand tons), and its domestic use in 2030, respectively, will increase by 1.04 times (from 0.89 thousand tons to 0.93 thousand tons). The returning excise duty for the sector did not yield the desired effect due to the lack of its production and the high excise duty on biodiesel, which is currently almost equal to the excise duty on diesel.

The results of the "Cancelling excise duty" Scenario indicate that the new support system will also have a positive impact on the development of the alternative fuel and biodiesel sector. The biodiesel production is expected to increase by 8 times from the Baseline scenario (from 0.01 to 0.08 thousand tons), but consumption will decrease by $2.2 \%$ (from 0.89 to 0.87 thousand tons). As for the impact of the excise duty system for the AMF sector, the following effects are expected: production will increase by 1.95 times from 6.61 thousand tons to 12.91 thousand tons, and its domestic use in 2030 will slightly increase from 89.98 to 90.38 thousand tons.

It should be noted that the main factor that influenced on the increase in production of AMF and biodiesel in the abolition of excise duty was the increase in producer prices, respectively, on alternative motor fuels and biodiesel. Thus, the price of the AMF increased by $5 \%$ from $2338.8 \mathrm{UAH}$. / $100 \mathrm{~kg}$ to 2 $456.1 \mathrm{UAH} / 100 \mathrm{~kg}$, biodiesel at 13.27\% - from $2637.3 \mathrm{UAH}$. / $100 \mathrm{~kg}$ to $2987.19 \mathrm{UAH}$. / $100 \mathrm{~kg}$ (Figure 4, Figure 5). 


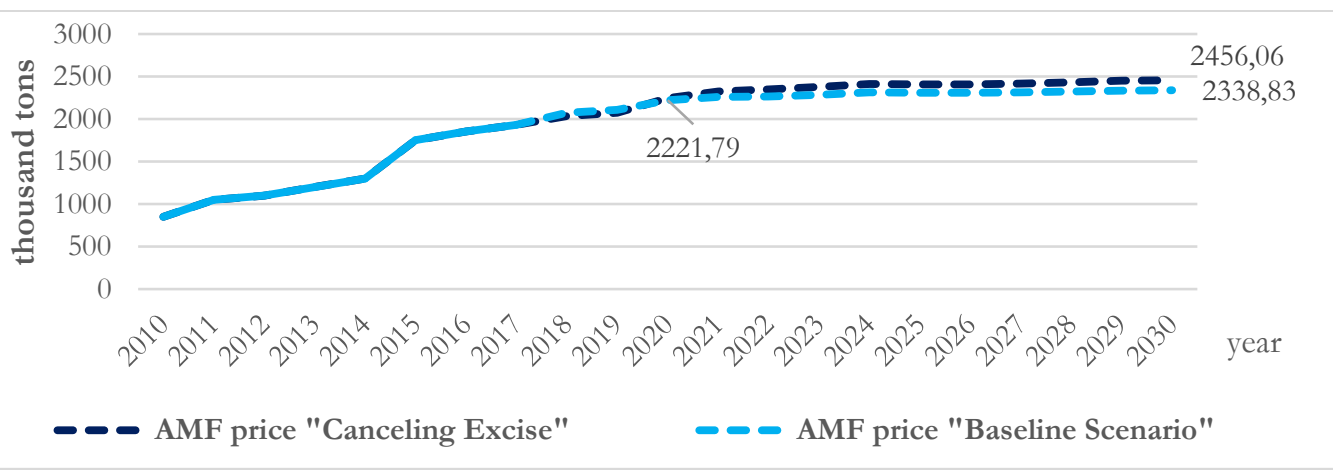

Figure 4. The AMF price in the scenario "Cancelling excise duty" compared to the Baseline scenario

Source: own evaluation.

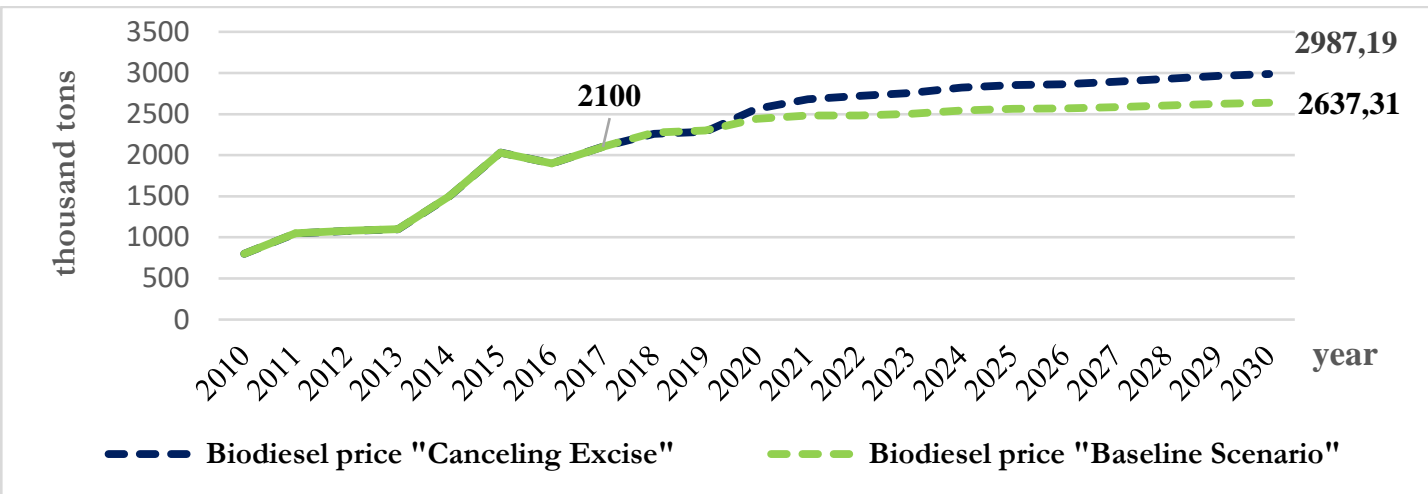

Figure 5. The Biodiesel price in the scenario "Cancelling excise duty" compared to the Baseline scenario

Source: own evaluation.

It should be noted that analysing the modelling results of the introduction of direct support for biofuel producers, will give impetus to the increased use of bioethanol and AMF almost 6 times by 2030 compared to the Baseline scenario. However, given the low level of bioethanol and AMF production and almost absence of biodiesel production, it is clear to reach the indicative target by 2020 necessary allocate a significant amount of funds: $5500 \mathrm{UAH} / 100 \mathrm{~kg}$ to reach bioethanol (AMF) consumption more than 500 thousand tonnes and $5500 \mathrm{UAH} / 100 \mathrm{~kg}$ to reach biodiesel consumption up to 79 thousand tonnes by 2030. The introduction of a system of refund of excise duty to AMF producers for the sold alternative fuel will stimulate an increase of AMF production, compared to the Baseline scenario by almost 4 times, and its use will increase by 1.2 times in 2030, respectively. The introduction of a system of refund of excise duty for biodiesel producers for the sold biodiesel will stimulate the increase of biodiesel production in the scenario 6 times compared to the Baseline Scenario, and its use in 2030, respectively, will increase 1.04 times. Excise duty reimbursement for the biodiesel sector did not produce the desired effect due to the lack of production and high excise duty on biodiesel, which is now almost on par with the excise duty on diesel. In general, the results of the "Cancelling excise duty" have shown an increase in production and consumption of AMF due to the introduction of the excise tax abolition system for AMF producers, and for biodiesel, there is an increase in its production, but compared to the Baseline scenario, consumption will decrease by $2.2 \%$. It should be noted that the main factor that influenced the increase in production of AMF and biodiesel due to the implementation of abolition excise duty was the increase in the producer price, respectively, for AMF and biodiesel. Thus, the AMF price increased by 5\% from $2338.8 \mathrm{UAH} / 100 \mathrm{~kg}$ to 
$2456.1 \mathrm{UAH} / 100 \mathrm{~kg}$, biodiesel by 13.27\% - from 2637.3 UAH / $100 \mathrm{~kg}$ to $2987.19 \mathrm{UAH} / 100 \mathrm{~kg}$. These all the above measures would contribute to achieving the mandatory indicative target of $10 \%$ biofuel consumption by the transport sector in Ukraine.

It was analysed other researches concerning achieving indicative targets in consumption biofuels until 2020. But all of them focused on the impact development of biofuels on food production, transport forecasts were analysed for emission changes relative to a reference with no biofuel, and the land claims were investigated in different scenarios for agricultural development.

For example, in India, biofuel initiatives have gained momentum with the national biofuel policy targeting 20\% blending of both petrol and diesel by 2017 (Subhashree Das, et al., 2011). For the study, was taken the southern Indian state of Karnataka as an example, aims at estimating the potential to achieve policy targets. The study spatially analysed land-use change owing to biofuel expansion and its effects on food production. In research were used an integrated modeling framework to simulate land-use change and bioenergy production under two scenarios - Industrial Economy (IE) and Agricultural Economy (AE). Results indicated that meeting the $20 \%$ blending target is a challenging goal to achieve under both scenarios. Bioethanol requirements can be nearly fulfilled ( $88 \%$ under IE and $93 \%$ under AE) because of sugarcane expansion. However, biodiesel demands cannot be fulfilled using only degraded lands as currently planned in India, but additional agricultural land (3-4\% of the total cropland) will be required for jatropha based biodiesel production. Food production will not be directly impacted until 2025, because the largest source of additional land could be short- and long-term fallows.

Frederiksen, P. (2013) was created two scenarios for biofuel introduction were developed - a conservative, following EU renewable energy targets for the transport of $10 \%$ in 2020 and keeping this level to 2030, and a more ambitious, with a biofuel share that increases to $25 \%$ in 2030. Bioethanol and biodiesel were selected fuel types, and the respective shares of these were assumed identical. Moreover, it was assumed that the growth in bioethanol use was increasingly provided by 2 nd generation bioethanol while 1 st generation bioethanol was kept at a $5 \%$ level. Forecasts of the road traffic to 2030 were developed - initially based on an oil price of $65 \$$ per barrel and later including a variant based on $100 \$$ per barrel. The transport forecasts were analysed for emission changes relative to a reference with no biofuel, and the land claims were investigated in different scenarios for agricultural development.

Three different scenarios were developed, assuming different targets for the contribution of biofuels in transport. All three scenarios were based on the general activity and energy projections used for the new framework on climate and energy, as described in the new "Trends to 2050" manuscript (EC, 2013). In the reference scenario used in this study, which is consistent with the Trends to 2050 study by the European Commission, biofuels constitute $93 \%$ of total renewable energy use in transport, thus assisting member states reaching their renewable targets. All these positive results were achieved on the basis of relevant policies that supported and promoted biofuels use and the acceptance of biofuels by the key market players (Dr. Leonidas Ntziachristos, et al., 2014).

Therefore, well - designed laws and regulations - supported by strong institutions and efficient administrative procedures - are necessary for biofuel production to prosper. Reducing excessive regulations of biofuel activities will improve the business environment that contributes to increasing competitiveness and growth of the sector.

\section{CONCLUSION}

Ukraine has a great competitive advantage in the production of biofuels as availability of the feedstock, fertile soils and supports through investments and know-how from abroad (Janda \& Stankus, 2017). Whereas the country disadvantageously exports feedstock to Europe for cheaper price and purchase 
expensive gas and oil instead. Thus, national interest should be shifted from the export of raw material to processing them into final biofuel products. Based on the experience of leading countries in the biofuels market, Ukraine should overcome energy dependence through the establishment of biofuel production and its utilization within the country.

According to Ukrainian Association of alternative fuels producers, main barriers that hinder Ukrainian biofuel industry from rising are as follows: high rate of excise duty that made the production of biofuel noncompetitive to traditional motor fuels and highly corrupted process of regulation of bioethanol production and fulfilment of standard technical requirements (Janda \& Stankus, 2017).

It is expected that in the Baseline scenario biofuel production will not face major changes, because the use of raw materials for food and feed consumption, as well as their export, will remain a more profitable option for Ukrainian producers. However, it is expected to motivate biofuel production by the introduction of a minimum of $10 \%$ biofuel use by the transport sector. In particular, the increase of demand for biofuel by at least $10 \%$ shall positively affect the respective domestic market price and, consequently, positively influence the use of commodities for biofuel production. Therefore, it might be the case that correctly specified domestic policy will trigger the development of biofuel production in Ukraine.

We propose to introduce obligatory admixture with traditional gasoline and diesel and return nonexcise production of alternative fuel and biodiesel fuel for a certain period (up to 10 years) to achieve the indicative target of $10 \%$ biofuels consumption by the transport sector and then promote the excise duty at an economically justified level of $10-20 \%$ of the excise tax rate on traditional gasoline and diesel. All of the above measures, such as direct support for liquid biofuels producers, tax incentives for producers and the introduction of a mandatory mixing rate, will contribute to achieving the indicative target of $10 \%$ consumption biofuels by the transport sector.

But it is worth noting that when conducting the research, we came across with the following limitations of the analysis: many assumptions due to lack of official statistical data, limited number of observations (throughout 2010-2017), difficulty in the regression's estimation, and as a result, carefulness in interpretation of the market simulation results.

The next steps of our research will become the implementation of other biofuel markets (biogas market) in AGMEMOD, statistical estimation of the respective equations; involvement of biofuel market experts (i.e., stakeholders) in the review of simulation results; adjustments and corrections of the equation parameters and/or assumptions.

\section{ACKNOWLEDGEMENTS}

The first modelling results were presented at the IAMO Forum 2018 "The Large-scale agriculture - for profit and society?”, 27th - 29th of June 2018, Halle (Saale) - Germany (https://www.iamo.de). We would like to express special gratitude to the team of the German-Ukrainian Agricultural Policy Dialogue for their constant assistance and recommendations regarding the modelling approach and implementation of policy scenarios in the model.

\section{REFERENCES}

AGMEMOD (2018). Agri-Food projections AGMEMOD for EU Member States. Retrieved April 21, 2019, from https://agmemod.eu.

ALIMENTERRE (2017). FAO: A new investment strategy is needed that puts agricultural producers at its center, Study/Report/Review, Platform \& Resources ALIMENTERRE. Retrieved April 21, 2019, from http://www.alimenterre.org.

APD (2017). Agricultural Outlook Ukraine 2017-2030. Baseline: projection of development of the agricultural sector in current economic and political frameworks and absent monetary state support. Kyiv. Retrieved April 26, 2019, from https://www.apdukraine.de. 
ATLASS Consortium (2010). Global Trade and Environmental Impact Study of the EU Biofuels Mandate, Final Report. Retrieved April 25, 2019, from http://www.ifpri.org/publication.

Banse, M., \& Grethe, H. (2008a). Effects of a Potential New Biofuel Directive on EU Land Use and Agricultural Markets. 107th EAAE Seminar "Modeling of Agricultural and Rural Development Policies". 29 January - 1 February 2008, Sevilla, Spain. <http://purl.umn.edu/6331>

Banse, M., Salamon, P., von Ledebur, O., Van Leeuwen, M., Bouma, F., Salputra, G., Fellmann, T., \& Nekhay, O. (2012). Impact of Russia and Ukraine on the international price formation and the EU markets - A Model based analysis, paper prepared for the 123rd EAAE Seminar 'Price Volatility and Farm Income Stabilization' held in Dublin, 23.-24.02.12.

Bioenergy Association of Ukraine (UABio) (2012). Status and prospects of biogas production in Ukraine. Retrieved April 23, 2019, from http://www.uabio.org/img/files/news/pdf.

Börjesson Hagberg, M., Pettersson, K., Erik O. Ahlgren (2016). Bioenergy futures in Sweden - Modeling integration scenarios for biofuel production. Retrieved April 21, 2019, from https://reader.elsevier.com.

Börjesson, M, Ahlgren, E. O., Lundmark, R., \& Athanassiadis, D. (2014). Biofuel futures in road transport - A modeling analysis for Sweden, 239-252.

CMU (2017), Energy strategy of Ukraine for the period up to 2035 "Safety, energy efficiency, competitiveness": approved by decree of the Cabinet of Ministers of Ukraine (CMU), No. 605-p, 18.08.2017. Retrieved April 25, 2019, from http://mpe.kmu.gov.ua.

Csaba Jansik, Lauri Kettunen, Heikki Lehtonen, \& Jyrki Niemi (2006). Agricultural policy analysis with the AGMEMOD model: A new super model takes the stage?. Retrieved December 15, 2019, from _ http://policy_analysis_with_the_AGMEMOD_mode.pdf.

European Parliament (2009), DIRECTIVE 2009/28/EC OF THE EUROPEAN PARLIAMENT AND OF THE COUNCIL of 23 April 2009 on the promotion of the use of energy from renewable sources and amending and subsequently repealing Directives 2001/77/EC and 2003/30/EC. Retrieved April 25, 2019, from https://www.ecolex.org/details/legislation.

Frederiksen, P. (ed). 2013. Scenarios for biofuels in the road transport sector - environmental and welfare economic consequences. Synthesis report from the REBECa project. Aarhus University, DCE - Danish Centre for Environment and Energy, 71 pp. Scientific Report from DCE - Danish Centre for Environment and Energy No. 46. http://dce.au.dk/udgivelser/vr/nr-1-50/abstracts/no-46-scenarios-for-biofuels-in-the-road-transport-sectorenvironmental-and-welfare-economic-consequences/

German-Ukrainian Agricultural Policy Dialogue (APD) (2018). www.apd-ukraine.de.

Gielen, D, Fujino, J, Hashimoto, S, \& Moriguchi, Y. (2003). Modeling of global biomass policies. Biomass and Bioenergy, 25, 177-195.

Gül, T., Kypreos, S., Turton, H., \& Barreto, L. (2009). An energy-economic scenario analysis of alternative fuels for personal transport using the Global Multi-regional MAR-KAL model GMM. Energy, 34, 1423-1437.

Hamulczuk, M., \& Hertel, K. (2009). AGMEMOD model - Structure and application for analysis and simulation of Polish agriculture sector. Metody Ilościowe w Badaniach Ekonomicznych X, 2009, str. 88-98.

IEA (2015). National Renewable Energy Action Plan (NREAP), International Energy Agency. Retrieved April 21, 2019, from https://www.iea.org.

Janda K., \& Stankus, E. (2017). Biofuels Markets and Policies in Ukraine, MPRA Paper No. 76747. Retrieved April 22, 2019, from https://mpra.ub.uni-muenchen.de.

Leonidas Ntziachristos, Dr. Giorgos Mellios, Dr. Petros Katsis (2014). The contribution of biofuels in transport sustainability post-2020.

Masharsky, A., Azarenkova, G., Oryekhova, K., \& Yavorsky, S. (2018). Anti-crisis financial management on energy enterprises as a precondition of innovative conversion of the energy industry: case of Ukraine. Marketing and Management of Innovations, 3: 345-354. Retrieved April 22, 2019, from http://doi.org.

NCSREPU (2018), Letter of the National Commission for State Regulation of Energy and Public Utilities (NCSREPU) No. 3671/17.3.2/7-18 from 16.04.2018.

OECD (2018), Aglink-Cosimo Biofuel Module Documentation. Retrieved April 21, 2019, from http://www.agrioutlook.org/about/Aglink-Cosimo-Biofuel-Documentation.pdf). 
Pérez Domínguez, I. \& Mueller, M. (eds) (2008). Modelling of energy-crops in agricultural sector models - a review of existing methodologies. JRC Scientific and Technical Reports. Institute for Prospective and Technological Studies, Seville, Spain.

Petra Salamon, Martin Banse, Trevor Donnellan, Marlen Hass, Roelof A. Jongeneel, Verena Laquai, Myrna van Leeuwen, Ioanna Reziti, Guna Salputra \& M Zirngibl (2019). AGMEMOD outlook for agricultural and food markets in EU member states 2018-2030. DOI:10.3220/WP1544622148000.

Schade, B. (2012), Future development of 2nd generation biofuels in transport considering learning rates, European Commission, JRCIPTS. $\quad$ Retrieved April 21, 2019, from https://www.systemdynamics.org/assets/conferences/2012/proceed/papers/P1108.pdf). SSSU (2017a), Agriculture of Ukraine - Statistical yearbook. State statistics service of Ukraine. Retrieved April 21, 2019, from http://www.ukrstat.gov.ua)..

Subhashree Das, Joerg A. Priess \& Christian Schweitzer (2011). Modelling regional scale biofuel scenarios - a case study for India.

Taheripour, F., Hertel, T., Tyner, W., Beckman, J., and Dileep, K. 2008. Biofuels and their By-Products: Global Economic and Environmental Implications. Presented at the 11th GTAP Conference, June 12-14 2008, Helsinki, Finland and at the 2008 American Agricultural Economics Association meeting in Orlando, Florida.

UKRSPYRT (2017). Data obtained through personal communication, public enterprise "Ukrspyrt". www://ukrfuel.org.

VAN TONGEREN, F., H. VAN MEIJL and Y. SURRY (2001). Global models applied to agricultural and trade policies: a review and assessment. In: Agricultural Economics, 26(2), 149-172.

Verkhovna Rada of Ukraine (2014). Tax Code of Ukraine. Retrieved April 20, 2019, from http://gogov.org.ua/wpcontent/uploads/2016/05/Tax-Code-of-Ukraine.pdf). 